\title{
Konferencja naukowa Sprawowanie Wieczerzy Pańskiej w dzisiejszej Europie (Warszawa, 21 kwietnia 2009)
}

Sekcja Liturgiki na Uniwersytecie Kardynała Stefana Wyszyńskiego w Warszawie zorganizowała 21 kwietnia 2009 roku konferencję naukową pod tytułem Sprawowanie Wieczerzy Pańskiej w dzisiejszej Europie.

Obrady rozpoczęła modlitwa prowadzona przez ks. dr. hab. Jacka Nowaka SAC, a następnie prodziekan Wydziału Teologicznego ks. prof. UKSW dr hab. Jan Przybyłowski przywitał zaproszonych gości i liczne audytorium. Podkreślił w swojej wypowiedzi, że świętowanie Eucharystią nie tworzy podziałów i granic w Europie. Ks. dr hab. Jacek Nowak SAC zauważył, że Wieczerza Pańska jest jednym z określeń Eucharystii. Jest Ona ostatnią ucztą Starego Testamentu, pierwszą ucztą Paschy Nowego Testamentu, podczas której Jezus Chrystus dał obrzęd nowy i zachętę do jego powtarzania: „To czyńcie na moją pamiątkę”. Właśnie podczas łamania chleba uczniowie idący do Emaus rozpoznali Jezusa. Konferencja naukowa chce przybliżyć wszystkim, jak we współczesnej Europie chrześcijanie rozpoznają Jezusa przy sprawowaniu Eucharystii.

Pierwszym prelegentem był ks. prof. Michael Fountaine z University of Bristol (Wielka Brytania), który przedstawił temat: Eucharistic diversity in Anglicanism. Prelegent był wychowany w środowisku anglikańskim, które opuścił i wraz z 40 osobami przeszedł do Kościoła rzymskokatolickiego. Przyjął w nim święcenia prezbiteratu w 2007 roku. Zaznaczył, że anglikanizm to najbardziej dyskutowana dzisiaj forma chrześcijaństwa. Eucharystia w anglikanizmie nie ma jednej obowiązującej interpretacji. Początki namysłu nad Eucharystią sięgają wydanej przez Edwarda VIw 1549 roku księgi The Book of Common Prayer. Była to pierwsza próba systematyzacji liturgii anglikańskiej, gdyż wcześniejsze opracowania były zbyt zbliżone do Kościoła rzymskiego. W kolejnej księdze liturgicznej z 1552 roku Wieczerza Pańska była rozumiana jako sakrament i komunia, a nie jako ofiara, ale podkreślano substancjalną obecność Jezusa Chrystusa w Eucharystii. Kolejnym etapem rozwoju anglikanizmu, jak zaznacza G. Dix, na którego prelegent się powoływał, było odejście od myśli Lutra, 
a przyjęcie tez Zwingliego. Nowa księga liturgiczna, fanatycznie antykatolicka, skreślała rubrykę o przyklęknięciu, wyrazie adoracji wobec realnej obecności Jezusa Chrystusa w Eucharystii. Widząc w anglikanizmie sprzeczne postawy, oscylujące między radykalnym protestantyzmem a rzymskim katolicyzmem, królowa Elżbieta I chciała znaleźć w nim stałe punkty, jednakowe w całym Kościele anglikańskim. Także przekład i upowszechnienie Biblii wpłynęły na anglikańską mentalność i reformę liturgiczną. Już na początku XX wieku widać ruch liturgiczny w anglikanizmie. Przez wieki Kościół anglikański kierował się zasadą lex orandi - lex credendi. W łonie Kościoła anglikańskiego nie można mówić o jedności, ale o różnorodności. Poszczególne grupy, sprawując liturgię, chcą manifestować swe teologiczne stanowisko. Stąd w Kościele tym można wyróżnić Low, Middle, High Church. Np. Low Church wyrasta z ruchu ewangelicznego. Podkreśla swoje protestanckie korzenie. Głosi cielesną obecność Jezusa Chrystusa, ale zarazem twierdzi, że nie może być ona lokalizowana. Kościół ten w liturgii charakteryzują: minimalna ilość rubryk, prezbiter ubrany w zwykły codzienny strój, minimum gestów rąk, zasada „celebrować to odczytywać", brak świec na ołtarzu, na którym jest tylko chleb i wino. Samą zaś Eucharystię spożywa się, a rzadko przechowuje. Różnorodność widać też w rozumieniu Eucharystii. Transsubstancjacja została przyjęta przez High Church i anglo-katolików, inne koncepcje mieszczą się między kalwinizmem a trydenckim katolicyzmem, często Eucharystia jest definiowana także jako anamneza. W anglikańskich księgach liturgicznych jest mowa o oficjum, tzn. o porannej i wieczornej modlitwie. Liturgia godzin była przez wieki wprowadzeniem do Eucharystii. Anglikanizm wypracował swoją formę śpiewu i recytacji. Forma ta jest pielęgnowana po dziś dzień. W większości ksiąg liturgicznych można zauważyć następującą koncepcję: życie chrześcijanina jest podróżą, do której zaprasza się także osoby niewierzące. Księga Common Worship podaje ramy i struktury celebracji, natomiast prezbiter w swojej wspólnocie może utworzyć własną formę celebracji i wybrać odpowiednie modlitwy. Jak podkreślał prelegent, jest to odejście od postulatu, aby całe imperium brytyjskie miało jeden ryt. Powołał się na zdanie Aidena Nicholsa, który zauważa, że w ten sposób powstała kompilacja różnych modlitw o różnym „nachyleniu teologicznym”. Prelegent podkreślił, że obecnie korzysta się także z różnych przekładów Biblii, niestety, często nieautoryzowanych. Kończąc, prelegent zapytał: czy różnorodność wzmacnia jedność w anglikańskim Kościele, czy można mówić o różnorodności w jedności? W 2008 roku biskup Sydney stwierdził, że diakoni mogą być przewodniczącymi Eucharystii. Tak to orzeczenie, jak i inne znane opinii publicznej sytuacje zachwiały jedność tego Kościoła. Jest to na pewno Kościół globalny, ale nie protestancko-genewski, nie rzymsko-katolicki. Jaka jest jego przyszłość? 
Drugim prelegentem był ks. dr Włodzimierz Nast (Chrześcijańska Akademia Teologiczna), który przedstawił zagadnienie Eucharystii w luteranizmie. Podkreślił, że reformator Marcin Luter, doktor biblijny, a nie liturgista, przedstawił 3 propozycje sprawowania mszy świętej. Propozycje te są zawarte w: Formula Missae, Deutsche Messe, Agendzie Saskiej. Według reformatora msza święta nie jest ofiarą, ale Sakramentem ołtarza, w którym jest prawdziwe Ciało i Krew Jezusa Chrystusa. Ale schemat Sakramentu ołtarza nie był taki sam we wszystkich reformatorskich wspólnotach. Często do podstawowego schematu konkretna wspólnota dodawała tradycję lokalną. Pierwsza część mszy to liturgia słowa, której najważniejszym punktem było i jest kazanie. Druga część to liturgia sakramentu ołtarza. Istotę tej części wyraża zasada: „Słowa niewidzialne stają się widzialne”. Luteranin rozumiał także mszę świętą jako Nabożeństwo Słowa i ołtarza, które jest dziękczynieniem, ale nie ofiarą ekspiacyjną.

Trzecim prelegentem był o. Leon Knabit OSB z Tyńca. Zaprezentował on temat: Msza święta $w$ tradycji benedyktyńskiej. Mnisi w niedzielę uczestniczyli we mszy świętej poza swoim miejscem zamieszkania i nieraz przynosili z niej Najświętszy Sakrament. Następnie był on rozdawany podczas oficjów w tygodniu. Samo życie monastyczne było znakiem obecności Jezusa Chrystusa wśród ludzi, stąd mało mamy opisów dotyczących Eucharystii. Eucharystia była oczywista. Zasada: ora et labora dotyczyła zadań związanych tak z życiem klasztornym, jak i Kościołem lokalnym. W początkowym okresie fundacji zakonnicy najczęściej na mszę świętą udawali się do parafii. Gdy we wspólnocie było więcej księży, msza święta była sprawowana w klasztorze. Od czasów Grzegorza Wielkiego msza święta była sprawowana codziennie. Zakonnicy rozumieli ją jako odzyskiwanie utraconego raju, źródło kontemplacyjnego stylu życia. Mszy świętej typowo benedyktyńskiej nie stworzono. Jasne było, że sprawuje się Eucharystię tak, jak w Rzymie. W okresie przed Soborem Watykańskim II sprawowano msze święte prywatne, tzn. odprawiane przez księdza benedyktyna z ministrantem, lub konwentualne w niedzielę i święta nakazane i nienakazane. Samo zaś sprawowanie Eucharystii zaowocowało mottem: módl się i pracuj, i nie bądź smutny. Według myśli benedyktyńskiej liturgia to nie tylko mysterium tremendum, ale dzieło ludu, dzieło dla ludu.

Kolejnym prelegentem był ks. dr Jerzy Tofiluk, rektor Prawosławnego Seminarium Duchownego w Warszawie. Zaprezentował on temat: Liturgia eucharystyczna w Kościele prawosławnym i różnice w tradycjach lokalnych. Podkreślił, że misterium Eucharystii jest związane z misterium Kościoła i odwrotnie - gdzie jest Eucharystia, tam jest Kościół. Chrześcijanie gromadzą się, aby tworzyć Kościół - jednoczą się na Eucharystii. Sama zaś li- 
turgia eucharystyczna to objawienie jedności ludu Bożego. Stąd w Kościele prawosławnym nie ma mszy świętej indywidualnej lub cichej, zawsze musi być lud. Gdzie dwóch albo trzech zebranych jest w imię Chrystusa, tam jest pełny Kościół. Sensem i celem życia chrześcijańskiego jest Eucharystia. Sama zaś Boska liturgia jest tym elementem, który wskazuje, że Królestwo Boże jest już obecne. W Eucharystii brak granicy między doczesnością a wiecznością, a sam człowiek to członek społeczności Kościoła i członek Chrystusa. Najczęściej sprawowane liturgie to: Jana Chryzostoma, Bazylego Wielkiego, św. Jakuba Apostoła, św. Grzegorza Papieża.

Ostatnim prelegentem był ks. mgr Kazimierz Gajowy SDB. Przedstawił on temat: Latynizacja liturgii eucharystycznej w obrządku maronickim. Próby powrotu do źódeł. Kościół maronicki to dzisiaj 6 milionów wiernych. Sam Kościół jest podzielony na 19 diecezji, ale w Libanie jest ich tylko 6. Początki Kościoła maronickiego sięgają czasów klasztoru św. Marona. Sam Maron był anachoretą z przełomu IV i V wieku. Eremici byli misjonarzami, którzy często nawoływali: ,Jeśli kochasz Boga, postaraj się, aby inni kochali Go razem z tobą”. Sam klasztor miał ogromny wpływ na sposób życia ludzi. Mnisi byli wzorem chrześcijańskiego życia. W VII wieku nastąpiła inwazja muzułmanów, przez co Kościół antiocheński przez wiele lat nie miał patriarchy. Ówczesny opat klasztoru św. Marona ogłosił swą niezależność, stając się patriarchą jako Jan Marun. Gdy nastąpiły prześladowania ze strony Bizancjum, Arabów i Turków, maronici wyemigrowali do Libanu. Kościół maronicki czuje się narodem.

W liturgii maronickiej używa się języka aramejskiego w dialekcie syriackim. W XVI wieku rozpoczęła się latynizacja liturgii maronickiej. Liturgia maronicka jest antiocheńska i taka jest też struktura mszy świętej. Modyfikacja liturgii została spowodowana wprowadzeniem kilku obrzędów w języku łacińskim: różańca, drogi krzyżowej, adoracji Najświętszego Sakramentu. Liturgii eucharystycznej kapłan nie jest w stanie sam sprawować. Oprócz prezbitera potrzebni są diakon, chór i wierni. Latynizacja to także używanie szat liturgicznychpochodzenia rzymskiego, łacińska architektura kościelna i wystrój świątyń. Wpływ na latynizację ma Kolegium Maronicke ufundowane w Rzymie w 1587 roku, które kształciło i nadal kształci pokolenia duszpasterzy. Ostatnimi czasy nowo założony instytut liturgiczny w Libanie analizuje maronickie korzenie i przywraca te elementy życia liturgicznego, które zostały zlatynizowane.

Całą konferencję naukową podsumował ks. dr Jan Rusiecki SDB, który zauważył, iż pomimo różnorodności form sprawowania Wieczerzy Pańskiej Eucharystia wśród chrześcijan ciągle jest źródłem obecności Jezusa Chrystusa w świecie. 